\title{
KONTRAK PSIKOLOGIS DAN MOTIVASI KERJA KARYAWAN PT. BAHTERA BERSAUDARA KRIAN
}

\author{
Agus Dwi Cahyo \\ Fakultas Psikologi Universitas Muhammadiyah Sidoarjo
}

\begin{abstract}
Work motivation can affects employee productivities that can be supported by the expectations that are desired the employee through the psychological contract. This study aims to investigate the relationship between psychological contract with employee motivation. This study used a quantitative correlational approach using the psychological contract as an independent variable $(\mathrm{X})$ and work motivation as the dependent variable (Y). Sampling techniques used proportionate stratified random sampling of 80 employees of PT. Primary Wisesa Mandiri. The data analysis used a correlational technique of product moment pearson which is calculated with SPSS 16.0 for Windows, obtained the correlation coefficient $(r)=0.446 ; \rho=0.001<\rho=0.01$. Correlation value is positive, it means there was a significant relationship, ie, the higher the psychological contract owned by the higher employee motivation.
\end{abstract}

Keywords: Psychological Contract, Work Motivation, Employee

\begin{abstract}
ABSTRAK
Motivasi kerja dapat mempengaruhi produktivitas kerja karyawan yang dapat didukung dengan adanya pengharapan yang diinginkan karyawan tersebut melalui kontrak psikologis. Penelitian ini bertujuan untuk mengetahui adanya hubungan antara kontrak psikologis dengan motivasi kerja karyawan. Penelitian ini menggunakan pendekatan kuantitatif korelasional dengan kontrak psikologis sebagai variabel independen $(\mathrm{X})$ dan motivasi kerja sebagai variabel dependen $(\mathrm{Y})$. Teknik sampling menggunakan proportionate stratified random sampling sebanyak 80karyawan PT. Pratama Wisesa Mandiri. Analisa data menggunakan teknik korelasi product moment pearson yang dihitung dengan SPSS 16.0 for Windows, diperoleh hasil koefisien korelasi $(\mathrm{r})=0,446 ; \rho=0,001<\rho=0,01$. Nilai korelasi bertanda positif artinya ada hubungan yang signifikan, yakni semakin tinggi kontrak psikologis yang dimiliki maka semakin tinggi motivasi kerja karyawan.
\end{abstract}

Kata kunci : Kontrak Psikologis, Motivasi Kerja, Karyawan

\section{PENDAHULUAN}

Pengelolaan sumber daya manusia tidak lepas dari faktor karyawan yang diharapkan dapat produktif sebaik mungkin demi mencapai suatu tujuan perusahaan. Karyawan merupakan aset utama pada perusahaan dan mempunyai peran yang strategis dalam perusahaan yaitu sebagai pemikir, perencana, dan pengendali aktivitas organisasi. Diperlukan adanya sebuah motivasi untuk memberikan dorongan sehingga diperoleh adanya semangat kerja bagi karyawan guna tercapainya tujuan perusahaan.

Martoyo (2007) menyatakan bahwa motivasi kerja adalah sesuatu yang menimbulkan dorongan atau semangat kerja atau dengan kata lain 
pendorong semangat kerja.Setiap pekerjaan memerlukan motivasi yang kuat agar bersedia melaksanakan pekerjaan dan mampu menciptakan kinerja yang tinggi secara bersemangat, bergairah, dan berdedikasi (Nawawi, 2003).

Rendahnya motivasi kerja yang dimiliki karyawan dapat mempengaruhi kualitas produktivitas kerjanya. Hasilnya, karyawan kurang menunjukkan prestasi kerja yang maksimal. Salah satu prediktor keberhasilan dari operasi sebuah perusahaan adalah ketika tercapainya prestasi kerja bagi karyawan sesuai dengan kemampuan yang dimiliki oleh karyawan tersebut. Adanya motivasi kerja yang tinggi, karyawan akan bekerja lebih giat dalam melaksanakan pekerjaannya. Sebaliknya dengan motivasi kerja yang rendah karyawan kurang mempunyai semangat kerja, mudah menyerah, dan kesulitan menyelesaikan pekerjaannya (Darmawan, 2013).

Berdasarkan hasil survey awal yang dilakukan oleh peneliti untuk tahun 2012 terkahir, PT. Bahtera Bersaudara Krian yang memiliki kurang lebih 398 karyawan yakni merupakan perusahaanyang bergerak di bidang produksi mesin kapal yaitu pembuat bahan-bahan dan mesin kapal yang meliputi mekank, tukang bubut, produksi, operator mesin, helper, security, cleaning service, driver dan tenaga pendukung lainnya. Diperoleh hasil data untuk setiap tahunnya sampai dengan kurang lebih 5 karyawan yang dikeluarkan atau resign dari perusahaan karena seringkali melakukan beberapa pelanggaranseperti masalah tidur, dalam pekerjaan tidak dapat mencapai target perusahaan, kurang smart, pekerjaan yang dikerjakan selalu tidak sama dari hasil kerja, sering absen (tidak masuk kerja tanpa alasan) dan lain-lain. Berdasarkan wawancara awal dari bagian HRD menyebutkan bahwa beberapa karyawan masih menunjukkan adanya motivasi kerja yang masih rendah dengan berbagai alasan yang disampaikan diantaranya adalah adanya ketidaksesuaian pemberian gaji dengan pekerjaan yang dilakukan.

\section{Mec-Cllleland}

(dalam Darmawan, 2013) menyatakan bahwa indikator-indikator motivasi sebagai dasar untuk bekerja dapat ditunjukkan melalui adanya Kebutuhan terhadap prestasi yaitu kebutuhan anggotaanggita organisasi untuk bekerja dengan baik dan berprestasi di organisasi yang dapat ditunjukkan dengan adanya perasaan terikat dengan bidang tugasnya, berusaha mengetahui prestasinya dan memperoleh umpan balik, tanggap terhadap situasi sukar dan menantang, keinginan menerima tanggung jawab dan standar prestasi kerja yang dapat diukur dan terpenuhi. Indikator lainnya adalah Kebutuhan terhadap kekuasaan yang artinya, kebutuhan anggota organisasi untuk mendapatkan kekuasaan dan mendapat penghargaan orang lain yang dapat dilihat dengan adanya rasa senang berargumentasi yang baik, mencari posisi wewenang yang dapat memberikan perintah dan pentingnya simbol status untuk memengaruhi orang lain. Lebih lanjut, indikator lainnya dapat ditunjukkan melalui kebutuhan terhadap afilliasi yaitu maksudnya, kebutuhan anggota 
organisasi untuk bekerja sama dengan orang lain yang dapat dilihat dengan adanya rasa senang bekerja sama dengan orang lain, berinteraksi dengan karyawan dan bersahabat dengan karyawan baru dan Kesediaan membantu orang lain.

Penentuan tinggi rendahnya motivasi kerja sangat bergantung pada keinginan karyawan dalam pencapaian tujuan-tujuan yang diinginkan, baik secara sadar maupun tidak sadar. Tujuan dapat pula diartikan sebagai suatu harapan untuk mendapat suatu penghargaan, suatu arah yang dikehendaki oleh motivasi itu sendiri. Pencapaian tujuan merupakan ujung kahir dari proses motivasi yang mengandung semua kegiatan untuk mencapainya. Setiap karyawan di suatu perusahaan memiliki tujuan pribadi, namun tujuan tersebut harus sejalan dengan tujuan perusahaan. Paling tidak hal tersebut berhubungan simetris dan saling memperkuat satu sama lain. Dengan demikian, kegiatan-kegiatan yang dilakukan karyawan dalam perusahaan tidak jauh menyimpang dari kegiatan perusahaan (Darmawan, 2013).

Ketidaksesuaian antara kegiatan karyawan dan kegiatan perusahaan akan berujung pada kesenjangan antara tujuan pribadi karyawan dan tujuan perusahaan dan dapat berakibat pada ketidakharmonisan kerja. Hal ini perlu dilakukan untuk menyeimbangkan antara tujuan pribadi karyawan dan tujuan perusahaan. Keseimbangan yang terbentuk antara tujuan pribadi karyawan dan tujuan perusahaan akan membentuk kontrak secara psikologis diantara keduanya (Darmawan, 2013).
Kontrak psikologis merupakan suatu persepsi karyawan tentang perwujudan dan kewajiban yang timbal balik terhadap perusahaan dan saling menguntungkan serta suatu harapan (tidak diucapkan) yang dimiliki masing-masing pihak, karyawan dan perusahaan, terhadap yang lainnya dan kewajiban yang dimiliki oleh dan kepada satu pihak dengan pihak lain. Kontrak psikologis ini dipahami dari sudut pandang karyawan bukan dari sudut pandang perusahaan (Schein dalam Rollinson, 2005).

Griffin (dalam Darmawan, 2013) menyatakan bahwa kontrak psikologis merupakan serangkaian ekspetasi yang dimiliki seseorang individu menyangkut apa yang dia kontribusikan untuk organisasi dan apa yang akan diberikan organisasi sebagai balas jasa. Jadi kontrak psikologis tidak tertulis di atas kertas dan tidak semua ketentuannya dinegoisasikan secara eksplisit antara individu dengan organisasi. Kontrak psikologis serupa kontrak legal standar dalam beberapa hal, tetapi bersifat kurang formal dan tidak terdefinisi secara baik.

Darmawan (2013) menyatakan bahwa kontrak psikologis yang terpenuhi akan memberikan pengaruh kepada sikap dan perilaku individu dalam organisasi. Kontrak psikologis yang sesuai dengan kesepakatan dari kedua belah pihak, karyawan maupun perusahaan akan meresa adil dan wajar, kedua belah pihak akan puas dan besar kemungkinan akan mempertahankan hubungan mereka. Sebaliknya bila salah satu pihak melihat ketidakseimbangan atau ketidakadilan dalam kontrak, persepsi 
tersebut dapat memicu perubahan. Dengan demikian, pelaksanaan kontrak psikologis yang wajar, akan dapat memberikan pemahaman bagi karyawan akan pemenuhan kebutuhan yang diharapkan oleh karaywan tersebut. Pemenuhan kebutuhan dapat menjadi salah satu pendorong karyawan untuk termotivasi dalam bekerja. Semakin tercapai kontrak psikologis yang dimiliki karyawan dalam perusahaan, maka semakin termotivasi karyawan untuk bekerja di perusahaan tersebut.

Terpenuhinya kontrak psikologis menurut Whyte (dalam Darmawan, 2013) tergantung dari tiga dimensi yaitu tingkat harapan bahwa perusahaan akan menyediakan apa yang diperoleh sesuai dengan apa yang diberikan karyawan, persepsi karyawan bahwa perusahaan telah menyediakan apa yang diperoleh sesuai dengan apa yang diberikan karyawan dan asumsi adanya kesamaan persepsi mengenai pertukaran; seperti pertukaran uang dan waktu kerja, pertukaran kebutuhan kerja, pertukaran kebutuhan sosial/rasa aman dengan kerja keras dan loyalitas, pertukaran kesempatan untuk aktualisasi diri dengan usaha yang kreatif untuk mencapai tujuan perusahaan atau kombinasi lainnya.

\section{METODE PENELITIAN}

Penelitan ini menggunakan pendekatankuantitatif korelasional, yakni penelitian yang bertujuan untuk mendeteksi sejauh mana variasivariasi pada suatu faktor berkaitan dengan variasi- variasi pada satu atau lebih faktor lain berdasarkan pada koefisien korelasi (Sumadi, 2004).

Teknik statistik yang digunakan dalam perhitungan hasil data adalah tehnik korelasi yakni suatu teknik statistik parametrik yang digunakan untuk menguji hubungan data rasio atau interval serta berfungsi untuk mengetahui besar kontribusi variabel independen terhadap perubahan variabel dependen (Sugiyono, 2008). Perhitungan analisa data dilakukan dengan menggunakan bantuan program SPSS versi 16.0 for windows.

Penelitian ini dilaksanakan pada karyawan PT. Bahtera Bersaudara Krian sebanyak 80 orang. proportionate stratified random sampling, yakni menentukan anggota sampel dari populasi yang mempunyai anggota/ unsur yang tidak homogen dan berstrata secara proporsional (Sugiyono, 2008).

Alat pengumpul data pada penelitian ini menggunakan dua skala psikologis yang dikonstruksikan sendiri oleh peneliti yaitu dengan skala kontrak psikologis dan skala motivasi kerjayang disusun berdasarkan model skala Likert yang sudah dimodifikasi dengan menghilangkan jawaban ragu-ragu dengan pertimbangan agar subjek tidak memberikan jawaban yang mengumpul di tengah (Hadi, 2000).

Pengujian validitasyang
dilakukan adalah dengan
menggunakan validitas isi yang
diestimasi lewat pengujian terhadap
isi tes dengan analisis rasional lewat
pengujian terhadap isi tes dengan
analisis rasional atau professional
judgment (Azwar, 2009). Hasil


analisis rasional terhadap isi tes dilakukan oleh orang ahli dan disetujui untuk dilakukan uji coba kepada sampel lain yang representatif dengan sampel penelitian.

Hasil dari analisis aitem diperoleh dengan melihat hasil $r_{\text {hitung }}$ yang dibandingkan dengan kriteria yang digunakan untuk item yang dinyatakan valid dalam uji coba validitas $r_{\text {hitung }}>r_{i x}=0,30$ (Azwar, 2009). Berdasarkan kriteria ini, hasil uji coba diperoleh item yang valid berjumlah 33 item dan yang gugur berjumlah 9 item pada skala kontrak psikologis dan item valid berjumlah 30 item dan yang gugur berjumlah 14 item pada skala motivasi kerja. Nilai koefisien korelasi item pada skala kontrak psikologis bergerak dari 0,330 ke arah 0,767 dan Nilai koefisien korelasi item pada skala motivasi kerja bergerak dari 0,313 ke arah 0,767. Butir item yang lolos dengan memiliki nilai koefisien korelasi yang tinggi dan disesuaikan dengan indikator-indikator dari variabel yang diukur, yang selanjutnya dapat digunakan sebagai skala untuk mengukur kontrak psikologis dan skala untuk mengukur motivasi kerja.

Pada perhitungan uji
reliabilitas, Pratisto
menyatakan bahwa alat ukur
dikatakan reliabel jika koefisien
korelasinya bernilai positif dan
koefisien korelasinya lebih besar dari
$\mathrm{r}_{\text {tabel }}\left(\mathrm{r}_{\text {alpha }}>\mathrm{r}_{\text {tabeel }}\right)$. Hasil uji reliabilitas
dari skala kontrak psikologis
diperoleh $\mathrm{r}_{\text {alpha }}=0,947$ dan item yang
memiliki nilai $\mathrm{r}_{\mathrm{i}}$ yang tinggi dengan
$\mathrm{r}_{\mathrm{iXY} \text { sebanyak } 33 \text { item dengan }}$
koefisien nilai Alpha pada setiap item
berkisar antara $0,943-0,947$ serta

hasil uji reliabilitas dari skala motivasi kerja diperoleh $r_{\text {alpha }}=0,949$ dan item yang memiliki nilai $r_{i}$ yang tinggi dengan $r_{i X Y}$ sebanyak 30 item dengan koefisien nilai Alpha pada setiap item berkisar antara 0,944 0,949. Hal ini dapat disimpulkan bahwa kedua skala tersebut dikatakan valid dan reliabel.

\section{HASIL DAN PEMBAHASAN}

Perhitungan korelasi untuk kedua data tersebut dengan melihat pada hasil analisis koefisien korelasi variabel kontrak psikologis dan motivasi kerja, yang diperoleh hasil koefisien korelasi $=0,446$ lebih besar dari $r_{\text {tabel }}=0,212(\mathrm{df}=80-2 ; \alpha=$ 5\%) dengan $\rho=0,001 ; \rho<0,05$. Artinya hubungan kedua variabel tersebut signifikan. Hasil nilai korelasi positif menunjukkan bahwa adanya hubungan yang searah yakni semakin tinggi kontrak psikologis yang dimiliki karyawan, maka semakin tinggi motivasi kerja karyawan dan sebaliknya semakin rendah kontrak psikologis yang dimiliki karyawan, maka semakin rendah motivasi kerja karyawan. Hal ini dapat disimpulkan bahwa hipotesa dalam penelitian ini dapat diterima.

Hasil penelitian di atas memperkuat kesimpulan Darmawan (2013), yakni kontrak psikologis yang benar akan memberikan pengaruh kepada sikap dan perilaku individu dalam organisasi. Pelaksanaan kontrak psikologis yang wajar, akan dapat memberikan pemahaman bagi karyawan akan pemenuhan kebutuhan yang diharapkan oleh karaywan tersebut. Pemenuhan kebutuhan dapat menjadi pendorong karyawan untuk termotivasi dalam bekerja. Semakin 
tercapai kontrak psikologis karyawan dalam perusahaan, maka semakin termotivasi karyawan untuk bekerja di perusahaan.

Esensi kontrak psikologis bilamana karyawan memberikan beragam kontribusi seperti upaya, keahlian, kemampuan, waktu, kesetiaan, dan lain-lain untuk perusahaan. Kontribuso-kontribusi diasumsikan akan memenuhi beragam kebutuhan dan keperluan perusahan. Perusahaan merekrut kayawan berbasis keahliannya, wajar perusahaan mengharapkan karyawan menggunakan keahlian tersebut saat bekerja dalam perusahaan. Sebagai imbalan untuk kontribusi-kontribusi ini, karyawan memberikan insentif kepada karyawan. Insentif berupa pemenuhan akan kebutuhan-kebutuhan karyawan (Darmawan, 2013).

Insentif merupakan bagian penting program motivasi kerja maupun bagian pembentuk semangat kerja. Bila kontribusi-kontribusi yang diberikan karyawan harus memenuhi kebutuhan-kebutuhan perusahaan, insentif-insentif yang diberikan perusahaan juga harus mampu memenuhi kebutuhan-kebutuhan karyawan. Dengan demikian, pelaksanaan kontrak psikologis akan membawa dampak lanjutan pada motivasi kerja karyawan terhadap kinerjanya dalam perusahaan tersebut (Darmawan, 2013).

Darmawan (2013) menyatakan bahwa kontrak psikologis merupakan hasil penilaian dari sudut pandang karyawan terhadap pemenuhan perusahaan terhadap kebutuhankebutuhan karyawan.
Bagi karyawan, aspek hubungan kerja yang dicakup kontrak psikologis adalah bagaimana perlakuan yang diterima dalam hal keadilan, persamaan, dan konsistensi, keamanan kerja, ruang lingkup untuk menunjukkan kompetensinya, harapan karier, keterlibatan, pemenuhan gaji dan tunjangan dan lain sebagainya.

Berdasarkan hasil penelitian yang telah dilakukan, maka saran yang dapat dikemukakan adalah sebagai berikut:

1. Bagi Karyawan

Hendaknya lebih meningkatkan motivasi kerjanya dengan menilai pada setiap kesepakatan yang telah dibuat dengan perusahaan sudah memenuhi sesuai kebutuhannya sehingga terbentuk kontrak psikologis.

2. Bagi Perusahaan.

Hendaknya dapat memenuhi kebutuhan-kebutuhan dari setiap karyawan sehingga karyawan juga dapat memenuhi setiap kebutuhan perusahaan yang berarti sudah terbentuk kontrak psikologis dan memberikan hasil kerja yang maksimal melalui motivasi kerja yang tinggi.

3. Bagi Peneliti Selanjutnya

Diharapkan pada peneliti lainnya yang hendak melakukan replikasi terhadap penelitian ini dapat mempertimbangkan variabel-variabel lain sebagai variabel kontrol yang dapat memaksimalkan hasil penelitian ini. 


\section{DAFTAR PUSTAKA}

Azwar, Saifuddin, 2009. Metode Penelitian. Yogyakarta: Pustaka Pelajar.

Candiasa, I Made. 2004. Analisis Butir Disertai Aplikasi dengan SPSS. Singaraja: Unit Penerbitan IKIP Negeri Singaraja.

Darmawan, Didit. 2013. Prinsipprinsip Perilaku Organisasi. Surabaya: Pena Semesta

Hadi, Sutrisno. 2000. Metodologi Research. Jilid 1. Yogyakarta: Andi Offset.

Martoyo, Susilo, 2007, Manajemen Sumber Daya Manusia. Yogyakarta: BPFE

Nawawi, Hadari. 2003. Manajemen Strategik Organisasi Non Profit Bidang Pemerintahan. Yogyakarta: Gadjah Mada University Press
Pratistio, Arif. 2004. Cara Mudah Mengatasi Masalah Statistik dan Rancangan Percobaan dengan SPSS 17. Jakarta: PT. Elex Media Komputindo.

Rollinson, D. 2005. Organisational Behavior and Analysis. An Integrated Approach $3^{\text {rd }}$ ed. England: Pearson Education Limited

Soetjiningsih. 2004. Tumbuh Kembang Remaja dan Permasalahannya. Jakarta: CV. Sagung Seto

Sugiyono. 2008. Metode Penelitian Kuantitatif, Kualitatif dan $R$ \& $D$. Bandung: Alfabeta.

Suryabrata, Sumadi. 2004. Psikologi Pendidikan. Jakarta: Rajawali Press. 